\title{
The Implementation of Local Cultural Identity in Form of 23 Character Values Taught in Islamic Boarding School
}

\author{
Sokip \\ IAIN Tulungagung, East Java, Indonesia \\ e-mail: irdan6000@gmail.com
}

\begin{abstract}
Education has very important role in term to build student personality and to help them having character values. This role to handle young generation cases nowadays, such losing local identity and preferring to western culture. Educational institution must insert character values in learning process. One of the institutions meant is Islamic Boarding School. In this case the writer wants to prove that Islamic Boarding School is suitable choice of school in term of character development for students because in teaching inserts several character values inside. To find the values, the writer uses library research method on chosen yellow books of Islamic Boarding School. As the result, to develop local identity in young generation, then it is found twenty-three character values that are being taught in Islamic Boarding School based on four yellow books studied.
\end{abstract}

\section{Keywords}

Character Values, Islamic Boarding School, Yellow Books

\section{Introduction}

Education is humanization, that is the effort to humanize human beings or help human to be able to realize toward own self with human dignity. Therefore, education purposes to help human to be what they want to be as their desires. Then to make them aware that their position is very glorious rather than another creature of Allah SWT as khalifah (leader) in this earth. Hence, the teacher or educator must understand the nature of humanity itself.

Education is a tool or means for a human to develop his personality and knowledge, therefore education is expected to have standard and well arrangement bases, curriculum, and clear theories. Moreover, an expected education must be relevant to the condition that still exist, and it is still going on.

According to the National Education System Act chapter 1 article 1 verse 1 , education is the realized and planned effort to create the condition of learning and process of learning, then its purpose is for students to actively be able to develop their potentials in terms of religious and spiritual power, self-control, also skill that needed by themselves, society, nation and country. 
In fact, our education nowadays is in decreasing era which is proved by most of the young generation who lost their local identity and culture as Indonesian. They are considered themselves in the style of western, being more modern in act of imitating western culture that can decrease the identity of who actually they are, loss of sense of mutual cooperation, not responsible, not being honest with certain cases, and still many others which those are the product of losing local identity. Moreover what something more to be worried if there is still many of the young generation (students) who involves in negative activities such as gang fight, drug, free sex, delinquency and so on. It happens because some factors, that the young generation is far from the thought of nationality and also, they are lost character values of religious education. Whereas religion education can be the base foundation for building character values in young generation personality and to keep them from those bad behaviors.

Therefore, if students' personality has been attributed a behavior (character), good morality, having such ability to manage themselves properly and making it as a habitual in the day along, then as the result later some phenomenon above can be decreased or even it will be disappeared for sure.

By the case above, it is expected that every educational institution must teach not only material of subjects to make students or young generation being intelligent however it also helps the students in having a local cultural identity in form of character values appropriately with the nation. Therefore, to realize the appropriate teaching system at school, it should be there one of the institutions that actually focuses mostly on growing character values toward the students. In this study, aims to answer the research question about the character values taught in Islamic Boarding as one of some educational institutions in Indonesia. At last, the writer takes one of the institutions is Islamic Boarding School. Islamic Boarding School aims to build students namely santri being someone who lives with a sense of character values in facing their day along. Then, the writer also predicts what are the character values taught in Islamic Boarding School toward santri. In addition, the way of studying is done by analysis some chosen yellow books that are considered as books taught in Islamic Boarding School toward the students.

\section{Theoretical Framework}

This study is under Indonesian Education especially Islamic Institution to gain the information and to answer the research problem belong. Islamic Boarding School or Pondok Pesantren is one of educational institution that has been declared since many years ago. The aim of Islamic boarding school is not sticking to get the power interest, money and worldly however it also about an obligation and dedication to God. Therefore, as one of the educational institutions, Islamic boarding school also has much responsibility toward building the character of its students namely Santri (Dhofier, 1981). According to Bennet (1991), school as education institution -includes Islamic boarding school-has an exceedingly important role in case of character education of children, especially for children who do not get character education at home. His statement has been proved by the reality that most of the children spend their time at school, and the things at school that is recorded in children memory will influence the development of their personality while being mature to be.

In learning system of Islamic boarding school is not only focusing on the term of cognitive and psychomotor that remarked with mastery in kinds of lesson and skill, but it also focuses on behavior or personality of students. In this case, an Islamic boarding school with confidence bring students to grow and develop their character values within the personality. As a result, they can be considered as a human who is able to recognize themselves with a strong and independent personality. Moreover, to be the whole human who has strong emotional and intellectual who can be able to recognize themselves, controlling themselves consistently, and having empathy. According to Syafe'i (2017) The existence of Islamic boarding school is an ideal partner for a government institution to jointly improve the quality of existing education as the basis for the implementation of social transformation through the provision of qualified human resources and having karimah character.

A character defines a series of attitudes, behaviors, motivations, and skills (Naim, 2012 p. 55). In this case, the contains of character consist of the act of desire to do the best, be intelligent, the critic in thinking, morality, be honest, and be responsible. Beside values gives definition about good and bad acts. However, what belongs to be studied here is all about a good act or good character values. People with ethical behavior has signed the power of their character (Gardner, 2007 p. 162). Therefore, having character values is necessary for everyone, especially the young generation to face the globalization era. Moreover, character values must insert in every curriculum of an educational institution. 
In addition, according to Najib Sulhan cited in Sokip (2018, p. 2) character education consists of four characters of Muhammad SAW prophet that is good to be applied as an example in life, those are shiddiq means be honest, amanah means be trustworthy or believable, tabligh means be transparent, and fathanah means be intelligent. Those four-character values belong to be the basic foundation for each education institution. However, the character values are actually still many based on certain yellow books that daily being taught by the teacher (ustad/ustadzah) to the students (santri) in Islamic Boarding School which those will be studied in this research.

\section{Results and Discussion}

From the result of studying several yellow books that consist of idzotun nasyiin book by Syekh Mustofa Ghulayaini, Ta'lim Mutaalim by Syekh Zarnuji, Washoyaa al Aba' lil Abna' book by M. Syakir, Nurul Al dholam syarh 'aqidatul 'awam and Sharh Tijan al Darori books, by M. Nawawi, then the writer find some character values that are being taught in Islamic boarding school, they are:

\section{Ulfah / Harmony}

Ulfah in language defines as harmony. In terminology, it is

$$
\text { الاستأناث بالناس والفرح بلقائهم }
$$

The meaning, feeling peaceful when lives with many people and be happy when meets them. In our daily language harmony is feeling peaceful, there is no fight, however, be appreciated and respect each other (Mas'udi, 1996).

Al-Ulfah is unity in love because of Allah, unity of love in obey to Him also its purity from Jahiliyah characters. It is one of the graces from Allah that is given to HIS servants after hidayah dan iman (faith) graces.

There is the advantage of having ulfah (peaceful) is that can give any goodness each other around you as a human being, and give hands each other than the condition is balanced, stable, and no fluctuation inside. Like what has been said by God: Wa' tashimu bi hablilahijami'awalatafarroqu, which means and be a stronghold for you all on the rope (religion) of God, and do not you be separated from each other

2. $\quad A k h o^{\prime} /$ brotherhood

Al Akho' in language defines as a brotherhood. In terminology, it is said as

هو رابطة بين الشخصين تحقق بينهما المودة

The meaning, brotherhood is the relation of the love relationship between two love people that each of both competes to do a good thing to others else. The form (act) of akho' is like giving help in the form of wealth, power (energy), apologizing each other act, the sincere heart, loyal, effort to decrease the problem (load), not giving loads each other, always stay to have good speak manner as the lesson of religion, propose to do good act and avoid it from the deny character and beg a goodness each other to Allah SWT (Mas'udi, 1996).

In Islam lesson, brotherhood and ukhuwwah are quite important and get enough attention portion that is significant enough. Hence, Al-Qur'an and Sunnah of prophet SAW gives a message and propose so that as Muslim being must always stay to keep brotherhood. In Surah Al-Hujurat: 10, Allah SWT gives a statement as follow:

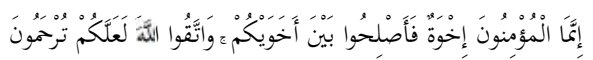

The meaning, the believers are brothers, so reconcile between your brothers, and remain conscious of God, so that you may receive mercy.

\section{Nadzofah / cleanness}

Islam is a religion that demands the cleanness of body, dress, and place. Therefore, everyone must always clean his body, spruce-up in term of hair, comb it and give it hair oil. Cleaning the ears by washing and wiping both ears with water, cleaning the mouth by gargling and using toothpaste, cleaning the nose by breathing then spray it out.

Hadits has explained that our prophet SAW always oiling and combing his hair. Cleanness is commanded, in term to keep health, to lose sadness, producing happiness, make friends be happy and to appear the grace of Allah. Related to this cleanness our prophet SAW states: 
The meaning, cleanness is half of faith. Therefore people who are low in keeping the cleanness of faith considers being questioning (Mas'udi, 1996).

There is a statement that saying "cleanness is beginning of health". It means that cleanness is quite important to keep because it can influence to health. Related to the important thing, Rasulullah SAW reminds that cleanness is half of faith. It means that faith person is obligated to pay attention to cleanness. As an example because it is so important than in praying (sholat) Muslim must take wudlu first before conducting praying. For someone who gets little hadast Rasulullah SAW says: "it is not accepted if doing pray (sholat) without wudlu. Meanwhile, for someone who gets large hardest, he is obligated or must do Junub.

\section{4. $\quad$ Fathanah / Intelligent}

Fathanah in language defines as cleverness, intelligent, capable or professional. Someone who is considered as this character has intelligent and capability while standing up in any kind of position wherever of the job. More specific, fathanah person is someone who is professional in his field. However, there is one thing that can not be forgotten is that this character is not all about intelligent, capability, or even be professional, but this character has own foundation that is based on high moral and glorious moral (Nawawi, n. d.; Amin, 1332).

Fathanah character does not always appear from the result of an educational institution. This type of person has high enthusiastic to stay always in learning and processing conditions. In every condition of his life is a suitable moment to have learning and getting any pieces of knowledge and insight. The base of doing activity is glorious moral, make him being an intelligent person who also educating others. Fathanah person is looked different rather than someone who does not have this character, in case of socializing in area of society.

This case has stated in Qs. Az Zumar : 9 :

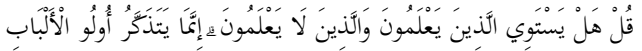

The meaning, Say, Are those who know and those who do not know equal? Only those possessed of reason will remember..

Fathanah character in psychology term defines as IQ. In the context of psychology process and cultural-social is said as intellectual development. Character values that contain in that context are clever, critical, creative, innovative, wonder, open-minded, productive, oriented to science and technology also effective (Kemendiknas, 2011).

\section{5. $\quad$ 'iffah / Avoid the forbidden thing}

Iffah in language defines as keep. Iffah in terminology as the attitude of keep own self from the forbidden thing (haram) and not laudable character. This character is part of glorious characters. From this character will appear many characters such as patience, simple life, love to give (care), love to peaceful, godfearing, calm, with authority, love to other people and shy. Iffah is visualized as a warehouse for people who do not have wealth and crown (no title) (Barja', $1385 \mathrm{H}$ ).

The quote of Washoya Al Abaa' Lil Abnaa' book that contains about the advice to how having iffah character is quoted as follow: " oh my son, iffah (take care of own self from the forbidden thing) is part of the glorious character, includes the character charitable people in a good way. That is why you have to have that glorious character so that can be the invested character in your soul.

Oh my son, receive this my advice. Remember every time, moreover when your desire makes you want to do a bad thing by following contemptible syahwat. Ask His protected from any kind of persuasion of Satan, by reading: A'uudzuubillaahaminas syaithaanir rajiim. Facing yourself to Allah with pure desire, ask the safe to Allah from any kind of persuasion of satan. Oh my son, actually Allah has the power to protect and take you to care with His rahmat and guidance.

\section{Muru'ah / good cultured}

Muru'ah is the character that encourages to hold on a glorious moral and good habit. The thing that can appear Muru'ah is the high aim and the glorious soul. Muru'ah is the sign of iffah character. Someone with this character, proving that he can keep himself in forbidden thing and something not good, also he is clean and kept from bad acts (Mas'udi, 1996).

Therefore someone with Muru'ah character must be had godfearing, not too like having fun, willing to receive the gift from Allah and not feeling jealous the gift of someone else. According to Shini (no years) states, that case above is related to our Prophet SAW saying:

$$
\text { ان الله يحب معالي الامور واشرفها }
$$


The meaning is Actually Allah SWT likes in virtuous and glorious cases.

Oh my son, someone who does not keep 'izzatin nafsi (self-glory), then there will be no advantage of his wealth and other things to reach the glory. Self-glory is the primary thing and it is more glorious than the glory of wealth. Half of self-glory is showing good moral in the face of mankind, although you are fakir. It does not show a wish of your need toward the person that close to you. Another half of self-glory is to be patience when you get obstacle in your life, by the laudable patience and return all of the things to Allah, do not you ask help except to your Rabb.

\section{7. $\quad$ Al Khilm / well-mannered}

Al Khilm in language defines as well mannered. In terminology, this character encourages its subject to do the goodness/respectful toward someone else, leaving the revenge toward annoyed people although he can reply it. The things that can cause someone has well mannered are: love to a stupid person, avoid the dispute, feeling shy and uncomfortable if the bad act to him is replied by the revenge. (Mas'udi, 1996; Barja' 1385 H).

hadits:

Our prophet SAW praises to the attitude of a well mannered person, as what has cited in his

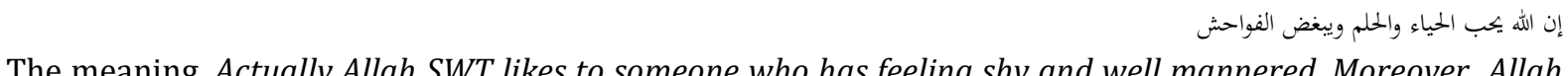
hates someone who has a cruel and rough character. As a result, well mannered or santun is the attitude of respectful, soft in saying and not make someone hurt.

In daily we demand to be well mannered and do a good thing to a fellow being. Neighbors are the example, they are close people around us who are being the first helpers while we get a problem. When there is an event at home, certainly the helpers are our neighbors.

\section{8. $\quad$ Amanah / Trustworthiness}

Amanah in language defines as trustworthiness. The antonym of that word is khianat (betrayal). In terminology, it considers as

$$
\text { القيام بحقوق الله تعالى وحقوق عباده }
$$

The meaning, conducting the rights and obligations to God. By the existence of amanah (Trustworthiness), it makes religion and faith are complete, the pride is kept and the wealth of properties are also kept well. Trustworthy (amanah) person will return borrowed goods to the owner, it is not less from the balance, also not showing someone shame to the public. He (amanah person) is conscious of anything that he gets as something which is going to be responsible on the face of God. Either it is the title, intelligent, health, wealth, properties, even himself, that consider as something which must be responsible. He believes that God will never forget, any sleep, and stay always controlling His servants doing. Even, the moving of the hidden heart (Barja' 1385 H; Amin, 1332).

In students context, amanah can be formed of parent's message, promise to your friend, a task from the teacher and so on. If a student has taken leave to his parent to go to school, then he must do it (go to school), not allow to playing. if playing means he does not keep his amanah. The Importance of Amanah Principle must be applied or conducted and taught to the children since they are so young even must make it as a habit, such as a quote from Washoya book below :

"Oh, my son, amanah (believable) defines as the better character of some laudable characters. Meanwhile, khianat (betrayal) defines as the worse character that is a contemptible and low character. Amanah is a dress for noble people and bookish. Actually, amanah and shiddiq (honest) are partly of characters that had by Rasul 'alaihimu Shalaatu Wassalaamu (hopefully shalawat and salam stay always given by them)."

9. Al sakho' / benignity

Al sakho'in language defines as benignity. In terminology is:

$$
\text { بذل المال من غير مسألة ولاشتقاق }
$$

The meaning, giving wealth properties willingly, without asked and it is not an obligation. Benignity is glorious character and laudable act, because inside it there is a relationship of heart and unity (Zarnuji, $\mathrm{n}$. d.; Barja' 1385 H).

Benignity person is a human who has a strong faith in God. By that faith, he believes that his wealth that has given to who need it will never run out. He believes that by giving Allah will give him the best gift in the afterlife later on. In Islam the character of benignity and moral is quite commanded to be applied by its followers in case of completing the religion itself, as what has cited in Qudsi Hadits Allah says: 
By the meaning, the region that I (Allah) ridla, will not make it more deserve except benignity and glorious character. Therefore, you all should glorify this religion by doing more of benignity and more in good moral (Mas'udi, 1996).

\section{Tawadlu'/ Modest}

Tawadlu' in language defines as modest. In terminology is :

$$
\text { خفض الجناح والانة الجانب من غير حصة ولا مذلة }
$$

The meaning, the character of being modesty with respectful and calm, not because of low and contemptible terms.

It means giving the right of every person, as appropriate with his position. Not raising up low people degree, also not take down the degree of glorious people (Al Ghalayaini, 1946). Someone with tawadlu' character will not take attitude arrogantly or proud to own self, although in fact, he is a rich man, smart and handsome. He never underestimates, insults, or differs socialization.

Talking about tawadlu', particularly in the world of education and knowledge, Al Zanurji states that this character absolutely must be had and applied in the life of Muslim, especially scientist and scholar. Tawadlu' means not being arrogant or proud of own self also not insulting and underestimate own self too much. The scientist should not has an arrogant character with the knowledge he has, because his knowledge is not much, for more if it is compared with the largest knowledge of Allah.

In his book, Ta'lim Al-Muta'alim Al-Zarnuji writes: "someone with knowledge should be tawadlu' (that is the character in the middle of arrogant and discouraging (small heart), make iffah, which more information can be found in the moral book"

Someone who has tawadlu' character will be raised up his degree by Allah and will get love from a human. Half of the people do not want to have tawadlu' attitude because they think that by having it can make their grade down toward fellow being until as the result people will hate them and taken away by other people. Actually, it is wrong thought or even it is only the reason that used by arrogant people to make true their arrogance. Because by having tawadlu' attitude someone will be added his grade and authority. Our Prophet SAW says: "and they are not tawadlu' because of Allah except Allah will make their grades higher" (HR.Muslim no.2588). It cannot be worried again that people who raised up their grades by Allah, definitely they will be loved by a human. In addition, it because Allah raises up their grades in their hearts. An Arab person has given advice to their son: "Be gentle to your followers certainly they will love you, and make their heart being modest, certainly they will raise your degree."

11. 'izzatu al nafsi / High soul

'izzatu al nafsi in language defines as high soul/confidence. In terminology is صفة بها يجعل الانسان نفسه في منازل الرفعة والاحترام. وسبهما رفعة الانسان قدر نفسه. The meaning, a character that can make someone is able to place himself in honor and glorious positions, and the appearance of 'izzatu al nafsi cause of he knows his own grade or position (Mas'udi, 1996).

The form or result of 'izzatu al nafsi is tajammul (strong) and sobr (patience) in facing the obstacles, not appearing his need, getting respect from people around, and getting goodness from Allah. That is the same as what Allah says:

The meaning is the owners of victory are only Allah, His messengers, and faith people.

$$
\text { ولثة العزة ولرسوله وللمؤمنين }
$$

'Izzatu al nafsi or confidence is feeling sure on his ability that has existed in his soul, and he can be able to show his ability to someone else. Someone with 'izzatu al nafsi character will always try and never fear to be failed and no give up.

12. Al 'adlu / fair

Al 'adlu in language defines as fair (in the middle). In terminology is

$$
\text { التوسط في الامور والسير فيها على وفق الشريعة }
$$

The meaning is an attitude which placing in the middle of the cases and working it based on syari'at of law. This character is included as a firm character, strong that does not show the attitude to take side to a certain person or group (Ghulayaini, 1949).

Fair is included as a laudable attitude which ridla by Allah. Therefore in Islam lesson, we demand to maintain justice in any kind of case and toward anyone even own self. In QS. An Nisa': 135 Allah says: 


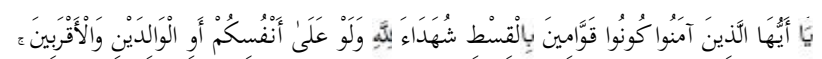

O you who believe! Stand firmly for justice, as witnesses to God, even if against yourselves, or your parents, or your relatives.

In deciding the case, justice must be the base in stand up. Anas bin Malik radhiyallahu 'anhu tells that

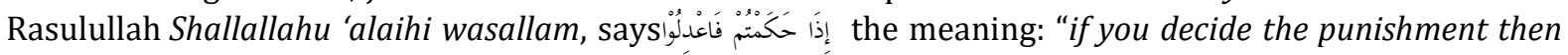
you must be fair!" (stated by Hasan by al-Albani in ash-Shahihah [no. 469]).

\section{Al ikhlas / sincere}

Al Ikhlas in language defines as sincere or sincere of heart, pure, and clean. In terminology, it is doing something good only because of Allah. Moreover only hope on His-ridla. According to Zanurji states that the antonym of this character is riya' or sum'ah. Riya' is showing off the charity to people so that they will give him such commendation, meanwhile, sum'ah is telling the charity to get sympathy from other people or getting attention and be the special face of others.

The place of sincere is in the heart. Therefore before conducting the worship, the heart must be managed first. The intention must be in order first because intention will be the determiner for the accepted charity of worship by Allah.

Next in the mubah charity or jawaz (that is allowed to be done or not), such as eat-drink, then if it is followed by the intention so that stay strong when having prayed and been god-fearing to Allah or so that be stronger in working as provision in conducting a pray for himself or his family, certainly that charity gets the reward, meanwhile without an intention, as an example only for getting full, then there is no reward (merit) (Riyadhatus salihin, Imam An Nawawi).

\section{Aljiddu / serious/diligent}

Al jiddu in language defines as serious or diligent. In terminology is being serious and diligent in trying to do something benefit. This character usually is encouraged by the desire to reach the aim. The antonym of this character is kaslan/lazy. The character of diligent is quietly important for the students because they will be easier in understanding the lesson. (Zarnuji, n. d.; Ghulayaini, 1949).

In the lesson of Islam used to our prophet SAW recognized as a diligent child. When he was 8 years old with his uncle Abu Thalib, he had helped to shepherd the livestock and helped the activity (bustle) at home. The habit of shepherd the goats are always done even he was able to help his uncle in the shop (as seller). Every task and obligation was always done well and full of responsibility. He had said that: take an effort as always for good life in this world looks like you will live forever, and take an effort for your happiness in afterlife looks like you will die tomorrow.

\section{Al- tafaul / optimistic}

Tafa'ul in language defines as optimistic. In terminology means feeling sure and followed by serious effort to be able to do something. People with this character will see the sense of life with full of happiness, safe, secure, and any properties of wealth. It seems like the quote that says:

It means whoever be serious, then he will make it.

People who have tafaul character will not look at the life of this world with narrow-minded, and full of the difficulty which faces on. They will look at this life with full of enthusiasm and full of belief that they are able to face and finish the whole of problems that faced by them. People with optimistic always have a high aim, hard work and never forget to stay always hope to rohmat from Allah for them. In the last of their efforts will be given over to Allah and anything that they get considered as best gift from Him.

\section{Qonaah / feel enough}

Qonaah in language defines as feeling enough/ accepting whatever it is. In the terminology of religion means feel enough with the gift of Allah and take away own self from unsatisfied character and feeling of less in much. By having this character does not mean must be lazy, as the result would not give the best effort to reach success. However, the act of Qonaah is recommended to take hard and serious effort, which if the result does not as what we expect it then we have to accept it with gratitude and not feeling upset also annoyed. Qonaah is visualized as savings that never be spent out or gone, as what our prophet says: 
The meaning is that Qanaah is the savings that never be lost

\section{Tawakkal / surrender}

Tawakkal in language defines as surrender or rely on. In terminology it is the attitude of surrender and relies on own self also hope whole of things only to Allah after doing such effort. The meaning of Tawakkal seems like when we have tried with all one's might, but still face the failure, we must be patience. In addition, the meaning patience here is not only quiet or silent, meanwhile, keep trying continuously with other ways still followed by praying (Barja' $1385 \mathrm{H}$ ).

In sight of Islam, someone should not give up if what he has tried does not the same as reality. Otherwise, he must accept willingly and still give over (surrender) to Allah SWT. The statement above has stated in Qs. Ali Imron: 159:

The meaning, and when you make a decision, put your trust in God; God loves the trusting.

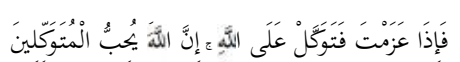

18. Al Syukr / be grateful

Al Syukr in language defines as feeling grateful. In terminology:

$$
\text { صرف العبد جميع ما انعم الله عليه الى من خلق لاجله }
$$

It means that using and thankful (be grateful) on all of the gift from Allah to him (human). Grateful consists of three things. First, with aolb (heart) it means always be remember to The Almighty with full of feeling love (mahabbah), polite (ta'dhim) and always be tashowaro jami'a ni'am minh (remember for all of the gift that has gotten). Second, with oral like utterance: al hamdulilah. Third, with part of the body $\left(a^{\prime} d l^{\prime}\right.$ ), it seems like we use that grace in saily life, we always do worship to Him every time and so on (Barja',1385 H).

The grace of Allah has been given to human since he was in intrauterine and when they were born and for a lifetime. Then, as a result, the human is not able to calculate it, it seems as His-saying: Qs. Ibrahim: 34:

The meaning, and if you were to count God's blessings, you would not be able to enumerate them.

Cause of many graces that have given to all of His-creatures, then it is sure that we are obligated to be thankful in the form of gratitude utterance.

19. Ash Shobr / Patience or tough

Ash Shobr in language defines as patience or tough to face something. In terminology is stated as:

$$
\text { الصبر هو من يصبر على الخطوب ويقابلها رابط الجأش لامن يقابلها مشدوها لايستقر على حال من القلق }
$$

It means that able to handle own self when facing the problem, no worry and feel want to escape on the problem, and always stay in the line of religion limitation that has determined. So, the capacity of patient can be said as always to be tough to endure something when given suffering as the test of Allah SWT, also never give up either in happy or sad condition.

As a result those can be concluded that patience is a laudable and glorious character. People with this character will accept the examination from Allah with full of willing, there is no disappointed feeling in their hearts. Patience does not mean be quite only without any care to change the condition to be better. Although willing to accepting the decision, however still followed by the enthusiasm and hard work with full of hope, effort and pray to Allah (Ghulayaini, 1949).

Az Zarnuji in his book of Ta'lim Mutaalim explains: See it, patience, and be able to endure is the superiority foundations in everything, but both are rarely done by people. therefore, then the students who want to be a success in their studies should have those characters above.

In another part of his book, Al-zarnuji also states that the journey of learning is the struggle that never is separated from troubled and suffering, he gives example in form of the journey of Prophet Musa AS when learning that almost give up and says:

It means that obviously, I face the trouble in my clan

$$
\text { لقد لقينا من سفركا هذا نصبا }
$$

Based on the above, it deserves if Ulama thinks that learning is glorious working for someone who is still in war (jihad), definitely getting big merit from God. Hence, the higher level of trouble that they faced in fighting, then the merit is also big, then Al-zarnuji also says that people with patience in facing the 
trouble in learning, they will get fruitful of knowledge more than anything in this world.

20. Al Syaja'ah/Brave

Al Syaja'ah in language defines as be brave. In terminology is stated as

$$
\text { الشجاعة هي الحد الوسط بين راذلتي الجبن والتحور ففي الجبن تفريط وفي تحور افراط وين الشجاعة السلامة }
$$

It means that brave character is the limitation in the middle between bad act jubnun (fear) and tahawwur (doing without thinking first). Fear is the attitude or act of frivol and tahawwur is too much (Ghulayaini, 1949).

Syaja'ah in Arabic means the brave or heroism, it is the character of someone who is able to be patience toward something if in his soul there is the brave of accepting examination or brave in doing something. The coward is difficult to have an attitude of patience and brave.

A child is taught to have an instinct as an entrepreneur who is courageous but still be considerate toward anything before achieving for his aim. ( Syaikh Musthafa al Ghalayin in the book of Idhatun Nasyi'in). Syajaah is divided into two types, they are:

a. Asy Syajaah harbiyah defines as the braveness that looks or appear, for example, braveness in war area when the time for war

b. Asy Syaja'ah nafsiyah defines as braveness to face the danger or suffering beyond war area, for example standing for the truth

Hakikat Asy Syaja'ah, the nature of braveness cannot be apart from the conditions as below:

a. Be brave to make right what is right and be brave to blame what is wrong

b. Be brave to defend the right of soul and physical

c. Be brave to defend the purity of religion and the honor of the nation

21. Tabligh/Transparent

Tabligh in language defines as transparent/ deliver.in terminology :

تبليغ ما أمر بتبليغه للخلق من الأحكام

It means delivering something that has commanded the creature about the law. In this globalization, open-minded is being the usual thing in organization or personally. The organization that is begun from the national institution and private institution, are always demanded to be open-minded, particularly in case of financial management. People with tabligh character absolutely have a nice personality, because they are in the type of warm personality, intimate and open minded. Their presence in the middle of society is being guidance and always be proud of (Nawawi, n. d.; Amin, 1332).

Tabligh people certainly deliver transparently to something that is being amanah. They will not hide or just cover something for own business. As what has shown by our Prophet SAW in Qs. Al-Fatir: 24 :

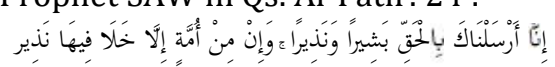

The meaning, we sent you with the truth; a bearer of good news, and a warner. There is no community but a warner has passed through it.

So, we should be able to invite someone else in doing something good, help each other and obey toward the commands of Allah SWT and his Rasul. We are not allowed to do something foolish and ignorance. In the case of the act to the children, we should also explain and apply since early because the character cannot be attributed to someone instantly.

Allah SWT also says about the command of delivering amanah in QS. An-Nisa verse 58

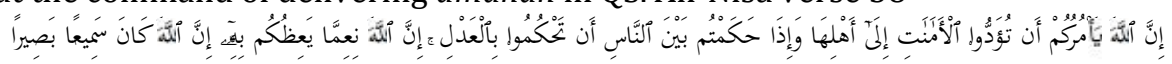

God instructs you to give back things entrusted to you to their owners. And when you judge between people, a judge with justice. God's instructions to you are excellent. God is All-Hearing, All-Seeing An Nisaa': 58).

\section{Al-Wathonah / Citizenship}

Al-wathoniah in language defines as love to the motherland. In terminology is stated as

$$
\text { الوطنية الحق هو حب اصلاح الوطاني والسعي في خدمته. }
$$

It means that loving and trying to build their nation for helping the development of their nation. People with nationality soul will always have faith in their nation and motherland. It includes people who want to learn than they have moral that invested in themselves, people who want to give some effort for the development of their motherland (Ghulayaini, 1949).

If this loving values toward this motherland are being taught to children since earlier then those values will grow until adulthood. From this expected generation like this, the life of mankind will be safe and fast to be realized which also decreasing external enemies of the country. The true education is the nature of life and knowledge is intravenous. There is no possibility to reach glorious life without knowledge and education. Education prevents of bad plan and competition, knowledge to the right path 
or way. How important this nationality education so that the country definitely gets freedom in education aspect and free from the bondage of a foreign country that wants to handle the talents of .

The important of nationalism in education is a novelty from the education system in a specific country, this case is supported from glorious desire to defend the area and the honor from foreign attack. The old generation nowadays will be dead and buried but motherland and area of the country will still exist. Who will defend the honor of country and nation if the young generation nowadays loses affection and faith toward their motherland?

23.

Shiddik / Honesty

Shiddiq in language defines as right or honest. In terminology it has the meaning :

الاخبار بما يطابقه الواقع وضده الكاذب.

The meaning, telling something as actually the same as reality, and the opposite meaning of shiddiq defines as lying

The meaning, telling something which not the same as reality

The truth and honesty are like two sides of currency inside of someone (Nawawi, n. d.; Mas'udi,1996).

Honest is a laudable characteristic that must be invested in the soul of children at an early age to imprint habitual honesty. As what had been shown by our prophet SAW that since childhood appeared his honesty in his utterance and act, friendly, polite, and not arrogant. Even because of his honesty, he gets a new title as "al Amin". Therefore, children must be habitually to say and do truthful and honest. If someone does lie once, his tongue will be habitually doing the same thing. (Syakir, 1926).

Below are the quotations in the book of Washoya Al Abaa'Lil Abnaa' about the importance of children to be honest:

"Oh my son, this is my will to you, if you like to say right as truth, as to how the students, then take a promise to me to not lie in any kinds of conversation. And say it: I promise to Allah to not lie to other people during the course my life" (Syakir, 1926).

"Remember! Actually, someone who do honest, every words and act will be a Dalil, even not need to know who state it actually (Al-Qur'an and Hadits). He will always be involved in meeting and asked some opinions in solving the problem. If you want to get that trusty, then try to stay honest as always in every talk. Moreover, The Almighty Allah surely gives guidance and help to the right way" (Syakir, 1926).

\section{Conclusions}

The possessions of values of character are very important to everyone especially the young generation. Those values must be applied in every learning process cause the better outcome is if the students can get a good personality and they know about their local identity. Local identity in this study, forming as character values taught in Islamic Boarding School to build character values toward the students. This aims to make the students namely santri all are having karimah character as what being the basis of Islam religion is Al-Qur'an and Al-Hadits. The character values taught in Islamic Boarding School based on the studying of four yellow books consist of 'idzotun nasyiin book by Syekh Mustofa Ghulayaini, , Ta'lim Mutaalim by syekh Zarnuji, Washoyaa al Aba' lil Abna' book by M. Syakir, Nurul Al dholam syarh 'aqidatul 'awam and Sharh Tijan al Darori books, by M. Nawawi found 23 values. Those are Ulfah / Harmony, Akho' / Brotherhood, Nadzofah / Cleanness, Fathanah / Intelligent, iffah / Avoid forbidden thing, Muru'ah / Good cultured, Al Khilm / Well mannered, Amanah / Trustworthiness, Al sakho' / benignity, Tawadlu' / Modest, Izzatu al nafsi / High soul, Al 'adlu / Fair, Al ikhlas / Sincere, Al jiddu / Serious, Al- tafaul / Optimistic, Qonaah / Feel enough, Tawakkal / Surrender, Al Syukr / Be grateful, Ash Shobr / patience or tough, Al Syaja'ah / Brave, Tabligh / Transparent, Al-Wathonah / Citizenship, Shiddik / Honesty. Then, 23 character values above are being the basis of teaching in Islamic boarding school. 


\section{References}

1. Dhofier, Z. (1981) Tradisi Pesantren: Studi Tentang Pandangan Hidup Kyai. Jakarta: LP3ES.

2. Gardner, H. (2007). Five Minds for The Future. Boston: Harvard Business School Press. pp. 162

3. Ghulayaini, Musthofa.(1946). Idzotun Nasyi'in. Mesir: Seeda.

4. Kemendiknas. (2011). Panduan Pelaksanaan Pendidikan Karakter. Jakarta: Balitbang dan Pukur.

5. Mas'udi. H. H. (1996). Taisirul al Kholaq fi 'Imi al Akhlaq. Terjemahan Fadli Sa'id An-Nadwi, Surabaya: Toko Kitab Imam.

6. Naim, N. (2012). Character Building. Jogjakarta: Ar-Ruzz Media. pp. 55

7. Nawawi, M. (n.d) Sharh Tijah al Darori. Translated. Jakarta : Dar'al Kutub al-Islamiyah

8. Shini, M.I \& 'Aziz, N. M. A \& Husen, M. T. (1973). Al Arobiyah li al Nasyiin Manhaju Mutakamilin Li ghoiri Al Nathiqin Bi al 'Arobiyah. Saudi Arabia: Penerbit Idaroh kutub al Madrosiyah.

9. Syafe'I, I. (2017). Pondok Pesantren Lembaga Pendidikan Pembentukan Karakter. Lampung: Universitas Negeri Raden Intan Lampung

10. Syakir, S. M. (1926). Wasiat Ayah kepada Anak Anaknya (dari kitab Asli Washoya Al Abaa lil Abnaa'. trans. Ahmad Sunarto. Al Miftah Surabaya.

11. Syakir, S.M. (1926). Wasiat Ayah kepada Anak Anaknya dari kitab Asli Washoya Al Abaa lil Abnaa'. Trans. Zeid Husein. Surabaya: Salim Nabhan

12. Zarnuji. (n. d.). Syarh Taklim Muta'alim. Semarang: Toha Putra 